Vol. 1 | No. 1 | Januari 2020 | Hal. 48 - 54

\title{
MENGGALI POTENSI SUMBER DAYA ALAM MENJADI KAWASAN PARIWISATA GUNA MENINGKATKAN PENDAPATAN DESA
}

\author{
Ahmad Siboy \\ Fakultas Hukum, Universitas Islam Malang \\ email: siboysalman@yahoo.com
}

\begin{abstract}
ABSTRAK
Desa Jambangan mempunyai banyak potensi alam salah satunya wisata air yang memiliki potensi untuk dikembangkan. Sumber bantal merupakan sumber kehidupan bagi masyarakat desa Jambangan, air yang mengalir ke rumah warga bersumber dari sumber bantal. Sumber bantal pada tahun 1980-an pernah menjadi tempat wisata bagi masyarakat desa Jambangan dan sekitarnya, tentunya karena sumber bantal dikelola dan dirawat dengan baik oleh penduduk sekitar, sehingga menjadikan sumber bantal. dijadikan tempat wisata yang menyenangkan. Teknik observasi atau pengamatan yang digunakan penulis untuk memperoleh gambaran yang tepat mengenai perilaku pemerintah dan masyarakat serta situasi-situasi yang berkaitan dengan topik di lokasi. Obyek wisata air sumber bantal menjadi potensi utama di desa Jambangan dengan suasana yang masih asri dan sejuk. Keindahan tersebut dapat dilihat dari pemandangan yang tercipta secara alami, tekstur tanah, dan kemurnian air. Jadi obyek wisata air sumber bantal ini sangat cocok sekali untuk para wisatawan baik anak muda atau yang sudah berkeluarga, baik wisatawan domestik maupun non-domestik. Wisata air sumber bantal memiliki potensi yang cukup besar sebagai tempat tujuan wisata. Untuk dapat mengembangkan obyek wisata air sumber bantal ini pemerintah desa Jambangan harus bekerjasama dan gotong royong dengan warga sekitar, memperbaiki fasilitas-fasilitas yang telah ada di obyek wisata air sumber bantal. Seperti menambah spot-spot foto yang menarik. Upaya untuk meningkatkan jumlah wisatawan yang berkunjung ke obyek wisata air sumber bantal salah satunya adalah dengan menggunakan sistem promosi melalui media sosial seperti instagram, facebook, whatapps, dan aplikasi sosial media lainnya.
\end{abstract}

Kata Kunci: jambanagan; desa wisata; sumber bantal.

\section{PENDAHULUAN}

Desa Jambangan terletak di kecamatan Dampit Kabupaten Malang, dengan jumlah penduduk 13.981 jiwa. Desa Jambangan mempunyai 4 dusun, dusun Krajan, dusun Grangsil, dusun Sumberputih, dan dusun Jegong. Desa Jambangan mempunyai banyak potensi alam dan potensi wisata air. Melimpahnya hasil pertanian dan perkebunan menjadikan desa Jambangan perlu dikembangan dari berbagai potensi yang dimiliki. Selain potensi sumber daya alam dan wisata air, desa Jambangan juga memiliki bank sampah yang sangat banyak memiliki manfaat dan keuntungan bagi masyarakat desa Jambangan. Bank sampah yang dikelola oleh pemuda desa Jambangan, menghasilkan pundi-pundi uang dan menambah perekonomian bagi masyarakat desa Jambangan melalui berbagai macam kreatifitas yang dibuat dari sampah dan memiliki nilai jual. Di samping itu, desa Jambangan memiliki potensi wisata air yang bisa dikembangkan dengan berbagai inovasi untuk menarik wisatawan, potensi wisata air tersebut adalah sumber bantal. 
Sumber bantal merupakan sumber kehidupan bagi masyarakat desa Jambangan, air yang mengalir ke rumah warga bersumber dari sumber bantal. Di samping sebagai sumber kehidupan masyarakat desa Jambangan, sumber bantal juga mempunyai potensi untuk dijadikan wisata air yang menarik. Air yang sangat jernih dan suasana yang masih asri menjadikan sumber bantal cocok untuk dijadikan tempat wisata air. Tentunya diperlukan sebuah inovasi terbarukan untuk mengembangkan potensi wisata air tersebut. Dengan adanya inovasi yang dilakukan, akan menarik wisatawan untuk berkunjung ke sumber bantal.

Sumber bantal pada tahun 1980-an pernah menjadi tempat wisata bagi masyarakat desa Jambangan dan sekitarnya, tentunya karena sumber bantal dikelola dan dirawat dengan baik oleh penduduk sekitar, sehingga menjadikan sumber bantal. dijadikan tempat wisata yang menyenangkan. Namun, sekitar 10 tahun yang lalu, sumber bantal mulai terbengkalai dan tidak terawat, sehingga tidak ada lagi pengunjung yang datang untuk rekreasi. Oleh karena itu, kami 33 mahasiswa dari kampus Universitas Islam Malang akan berusaha untuk menghidupkan kembali wisata air sumber bantal untuk masyarakat desa Jambangan dan sekitarnya.

Secara etimologi, pariwisata terdiri dari dua kata yaitu pari dan wisata. Pari berarti banyak, lengkap, berkali kali, sedangkan wisata berarti perjalanan atau bepergian. Maka pariwisata artinya adalah suatu perjalanan yang dilakukan secara berkali-kali.

Definisi pariwisata telah banyak dikemukakan oleh para ahli di bidang pariwisata, namun dalam definisi tersebut masih terdapat beberapa perbedaan dalam pendefmisian. Beberapa pengertian atau definisi pariwisata yang pemah dikemukakan oleh para ahli dalam bidang pariwisata, antara lain:

1. Menurut Hunzieker dan Kraf (1942), pariwisata adalah keseluruhan fenomena dan hubungan hubungan yang ditimbulkan oleh perjalanan dan persinggahan manusia di luar tempat tinggalnya, dengan maksud bukan untuk menetap di tempat yang disinggahinya dan tidak berkaitan dengan pekexjaan yang menghasilkan upah. Perjalanan yang dilakukan biasanya didorong oleh rasa ingin tahu untuk keperluan yang bersifat rekreatif dan edukatif (dalam Kohdyat, $1996: 2$ )

2. Menurut McIntosh dan Gupta (1980: 28), pariwisata didefinisikan sebagai gabungan gejala dan hubungan yang timbul dari interaksi wisatawan, bisnis, pemerintah tuan rumah, serta masyarakat tuan mmah dalam proses menarik dan melayani wisatawan wisatawan ini serta para pengunjung lainnya.

3. Menurut Wahab (1996), pariwisata merupakan suatu aktivitas manusia yang dilakukan secara sadar yang mendapat pelayanan secara bergamian diantara orang-orang di dalam negara itu dan daerah lain (daerah tenentu) untuk sementara waktu dalam mencari kepuasan yang beraneka ragam dan berbeda dengan apa yang dialaminya di tempat ia memperoleh pekerjaan tetap (dalam Andy Aryawan, 2002: 10).

Dari beberapa pengenian pariwisata di atas terdapat satu kesamaan dalam pengertian tentang pariwisata yaitu bahwa kegiatan ini merupakan fenomena yang ditimbulkan oleh salah satu bentuk kegiatan manusia yaitu kegiatan perjalanan/trevelling. Berdasarkan beberapa pengertian tersebut diatas, kegiatan manusia yang dilakukan dalam rangka rekreasi atau untuk mencari menikmati suasana yang berbeda membutuhkan suatu obyek atau tempat untuk singgah. Pemandangan alam, dalam hal ini adalah pemandangan sumber berperan sebagai suatu obyek atau atraksi untuk memenuhi kebutuhan manusia dalam melakukan kegiatan wisata.

Kawasan pada hakekatnya merupakan suatu wilayah yang lingkupnya lebih sempit. Menurut UU No. 24 Tahun 1992 dijelaskan bahwa wilayah adalah ruang yang merupakan kesatuan geografis beserta segenap unsur terkait padanya yang batas dan sistemnya 
ditentukan berdasarkan aspek administratif atau aspek fungsional. Sedangkan kawasan adalah wilayah dengan fungsi utama lindung atau budidaya.

Kawasan pada hakekatnya merupakan suatu wilayah yang lingkupnya lebih sempit. Menurut UU No. 24 Tahun 1992 dijelaskan bahwa wilayah adalah ruang yang merupakan kesatuan geografis beserta segenap unsur terkait padanya yang batas dan sistemnya ditentukan berdasarkan aspek administratif atau aspek fungsional. Sedangkan kawasan adalah wilayah dengan fungsi utama lindung atau budidaya.

Berdasarkan UU No. 9 Tahun 1990 dijelaskan bahwa pengertian kawasan wisata adalah suatu kawasan yang mempunyai luas tertentu yang dibangun dan disediakan untuk kegiatan pariwisata. Apabila dikaitkan dengan pariwisata air, pengertian tersebut berarti suatu kawasan yang disediakan untuk kegiatan pariwisata dengan mengandalkan obyek alau daya tarik kawasan perairan. Pengertian kawasan pariwisata ini juga diungkapkan oleh seorang ahli yaitu lnskeep (1991:77) sebagai area yang dikembangkan dengan penyediaan fasilitas dan pelayanan lengkap (untuk rekreasi/relaksasi, pendalaman suatu pengalaman/kesehatan).

Sedangkan pengertian kawasan pariwisata secara umum adalah suatu kawasan dengan luas tenentu yang dibangun atau disediakan untuk memenuhi kebutuhan pariwisata dan jasa wisata. Dalam lingkup yang lebih luas kawasan pariwisata dikenal sebagai Resort City yaitu perkampungan kota yang mempunyai tumpuan kehidupan pada penyediaan sarana dan prasarana wisata seperti penginapan, restoran, olah raga, hiburan dan penyediaan jasa tamasya lainnya. Apabila kawasan pariwisata tersebut mengandalkan pemandangan alam berupa kawasan perairan sebagai ciri khasnya, maka penyediaan sarana dan prasarana serta hiburan atau atraksi wisatanya diarahkan untuk memanfaatkan dan menikmati kawasan perairan tersebut.

Daya tarik wisata merupakan potensi yang menjadi pendorong kehadiran wisatawan ke suatu daerah tertentu. Obyek dan daya tarik wisata adalah yang menjadi sasaran perjalanan wisata. Hal-hal yang menarik bagi wisatawan untuk berkunjung ke suatu tempat tujuan wisata menurut Marrioti adalah benda-benda yang tersedia di alam semesta dan terbentuk dengan alami, hasil ciptaan manusia berupa benda-benda bersejarah, kebudayaan dan keagamaan, serta tata cara hidup masyarakat yang berupa kebiasaan yang disebut dengan adat istiadat.

Menurut J.S. Badudu, potensi adalah kemampuan yang mempunyai kemungkinan untuk dikembangkan, kekuatan, kesanggupan daya. Potensi pariwisata adalah segala hal dan keadaan baik yang nyata dan adapat diraba, maupun yang tidak dapat diraba, yang digarap, diatur dan disediakan sedemikian rupa sehingga dapat bermanfaat atau dimanfaatkan atau diwujudkan sebagai kemampuan, faktor dan unsure yang diperlukan atau menentukan bagi usaha dan pengembangan kepariwisataan, baik itu berupa suasana, kejadian, benda maupun layanan atau jasa.

Menurut Swastha dan Irawan (1990: 67) strategi merupakan suatu rencana yang diutamakan untuk mencapai arah tujuan tersebut. Beberapa obyek wisata mungkin mempunyai tujuan yang sama akan tetapi strategi yang dipakai untuk mencapai tujuan tersebut belum tentu sama. Berdasarkan definisi tersebut dapat diketahui bahwa startegi yang dibuat berdasarkan tujuan yang ingin dicapai.

Sedangkan menurut Kotler (2001) mendefinisikan strategi adalah pendekatan produk yang akan digunakan guna mencapai sasaran yang telah ditetapkan terlebih dahulu.

Startegi pemasaran adalah logika pemasaran dimana perusahaan berharap untuk menciptakan nilai pelanggan dan mencapai hubungan yang menguntungkan (Kotler dan Amstrong, 2001: 58). Dan sedangkan menurut Lamb, Hair, Mc Daniel (2001) strategi 
pemasaran merupakan kegiatan menyeleksi dan penjelasan satu atau beberapa target pasar dan mengembangkan serta memelihara satu bauran pemasaran yang menghasilkan keputusan bersama dengan pasar yang dituju.

\section{METODE}

Observasi atau pengamatan digunakan untuk memperoleh gambaran yang tepat mengenai perilaku pemerintah dan masyarakat serta situasi-situasi yang berkaitan dengan topik di lokasi. Teknik observasi dilaksanakan pengamatan secara langsung terhadap obyek yang diteliti dalam kurun waktu yang cukup lama. Teknik observasi merupakan kegiatan yang pemusatan perhatian terhadap suatu objek dengan menggunakan seluruh alat indera (Sugiyono, 2011). Pada dasarnya observasi sebagai teknik utama untuk mendapatkan informasi dimana dalam proses ini, penulis melihat perilaku keadaan (setting)

alamiah, melihat dinamika, melihat gambaran perilaku berdasarkan situasi yang ada (Sugiyono, 2011). Penggunaan teknik observasi yang terpenting adalah mengandalkan pengamatan dan ingatan penulis. Akan tetapi untuk mempermudah pengamatan dan ingatan, maka penulis menggunakan (1) catatan-catatan, (2) alat elektronik seperti recorder dan kamera (3) pengamatan, (pemusatan pada datadata yang tepat), dan (4) menambah persepsi atau pengetahuan tentang obyek yang diamati.

Dalam hal ini, penulis menggunakan analisis data deskriptif kualitatif. Dimana data yang di peroleh di lapangan nantinya akan dianalisis secara deskritif kualitatif. Spradley (1980) menyatakan bahwa analisis merupakan cara berfikir. Hal itu berkaitan dengan pengujian secara sistematis terhadap sesuatu untuk menentukan bagian, hubungan antar bagian, dan hubungannya dengan keseluruhan.

Berdasarkan hal tersebut peulis menggunakan metode analisis data dengan cara mencari dan menyusun secara sistematis data yang diperoleh pada saat observasi (catatan lapangan) dan hasil dokumentasi dengan cara mengorganisasikan data kedalam kategori, menjabarkan kedalam unit-unit, menyusun kedalam pola memilih mana yang penting dan yang akan dipelajari, dan membuat kesimpulan sehingga mudah dipahami oleh diri sendiri maupun orang lain.

\section{HASIL DAN PEMBAHASAN}

\section{Potensi Sumber Bantal Sebagai Tujuan Wisata}

Desa Jambangan, Kecamatan Dampit, Kabupaten Malang meruapakan salah satu wilayah yang berpotensi di bidang pariwisata. Wilayah ini berpotensi sebagai area wisata karena banyak tempat-tempat wisata yang menyuguhkan keindahan alam yang tercipta dengan alami. Dan yang dibahas disini adalah wisata air sumber bantal. Obyek wisata air sumber bantal menjadi potensi utama di desa Jambangan dengan suasana yang masih asri dan sejuk. Keindahan tersebut dapat dilihat dari pemandangan yang tercipta secara alami, tekstur tanah, dan kemurnian air. Jadi obyek wisata air sumber bantal ini sangat cocok sekali untuk para wisatawan baik anak muda atau yang sudah berkeluarga, baik wisatawan domestik maupun non-domestik.

Sekitar tahun 1980-an, sumber bantal pernah menjadi obyek wisata air dan dikelola dengan baik oleh masyarakat desa Jambangan. Namun, sekitar 10 tahun yang lalu, sumber bantal tidak lagi dijadikan sebagai tempat wisata karena tidak ada yang mengelola dan merawat. Sehingga, kami KKN-PPM Unisma akan menghidupkan kembali wisata air sumber bantal dengan berbagai inovasi yang telah kami susun.

Potensi pendukung yang ada di obyek wisata air sumber bantal yang dimanfaatkan oleh warga sekitar dan dapat sebagai mata pencaharian atau tambahan 
penghasilan bagi warga sekitar, yaitu dengan membuka warung makan, berjualan minuman, dan makanan ringan, maupun jasa parkir.

\section{Potensi Obyek Wisata Air Sumber Bantal Berdasarkan Analisis SWOT (Strength, Weaknesses, Opportunity, Threats).}

Dalam menyusun strategi yang tepat dalam meningkatkan pendapatan maka perlu dilakukan analisis faktor intern dan faktor ekstern. Dalam menganalisis hal tersebut dapat dilakukan dengan menggunakan analisis SWOT yang meliputi: kekuatan, kelemahan, kesempatan yang ada serta adanya ancaman yang akan terjadi.

a. Kekuatan (Strength)

Obyek wisata air sumber bantal memiliki potensi yang cukup besar sebagai tempat tujuan wisata. Obyek wisata air sumber bantal mempunyai potensi yang dapat sebagai sumber kekuatan yang terletak pada kualitas air yang masih murni belum terkontaminasi oleh limbah apapun. Selain itu, kondisi air yang tenang sangat cocok untuk berenang dan bersantai. Cocok untuk anak-anak, anak muda maupun yang sudah berkeluarga. Obyek wisata air sumber bantal ini merupakan aset yang potensial yang dimanfaatkan dan dikelola di bawah naungan pemerintahan desa Jambangan.

b. Kelemahan (Weaknesses)

Kelemahan dari obyek wisata air sumber bantal yang saat ini sulit untuk diatasi oleh pemerintahan desa Jambangan adalah dalam hal mengembangkan sarana penunjang luar yang masih terhalang oleh hak milik. Sarana penunjang luar yang dimaksud disini adalah seperti lahan parkir, di obyek wisata air sumber bantal ini terdapat lahan parkir akan tetapi belum memadai dikarenakan tanah kosong yang diperuntukkan sebagai lahan parkir masih terbilang sangat sempit.

c. Kesempatan (Opportunity)

Untuk dapat mengembangkan obyek wisata air sumber bantal ini pemerintah desa Jambangan memiliki kesempatan yaitu dengan cara bekerja sama gotong royong dengan warga sekitar, memperbaiki fasilitas-fasilitas yang telah ada di obyek wisata air sumber bantal. Seperti menambah spot-spot foto yang menarik, dengan hal tersebut dapat meningkatkan jumlah wisatawan yang berkunjung ke obyek wisata air sumber bantal. Pembuatan gazebo juga sangat diperlukan untuk bersantai dan beristirahat.

d. Ancaman (Threats)

Menurut pandangan kami, yang paling mengancam obyek wisata air sumber bantal adalah benacana alam, seperti gempa bumi, tanah longsor, dan kejadian alam lainnya. Kontur tanah yang miring menjadikan akses jalan menuju sumber bantal menjadi ancaman bagi wisatawan yang berkunjung, dengan kondisi tanah yang licin dan gembur ketika turun hujan. Oleh karena itu, kami membuat akses jalan dengan cara membuat jalan tangga setapak untuk memudahkan wisatawan yang berkunjung ke wisata air sumber bantal. Jalan tangga setapak juga bernanfaat untuk meminimalisir terjadinya longsor.

\section{Strategi Pengembangan Obyek Wisata Air Sumber Bantal Agar Dapat Menjadi Tujuan Wisata}

Warga sekitar dibawah naungan pemerintahan desa Jambangan telah membuat strategi agar obyek wisata air sumber bantal dapat dikenal, sebagai tempat tujuan wisata dan memaksimalkan potensi yang ada. Langkah-langkah yang digunakan dalam pengembangan wisata air sumber bantal dimulai dari menyusun konsep rencana 
pengembangan dan memaksimalkan potensi-potensi yang dimiliki obyek wisata air sumber bantal. Selain itu, warga sekitar juga berupaya mempromosikan wisata air sumber bantal agar lebih dikenal oleh wisatawan dan nantinya banyak wisatawan yang berkunjung ke tempat tersebut. Strategi yang digunakan antara lain:

a. Konsep untuk mengembangkan obyek wisata air sumber bantal

Konsep yang digunakan dalam pengembangan obyek wisata air sumber bantal adalah bertumpu pada alam. Artinya dalam konsep pengembangan obyek wisata air sumber bantal tidak menghilangkan unsure nilai alamiah. Maka dari itu, pengelola dan pemerintahan desa Jambangan berusaha mengoptimalkan potensi yang ada di obyek wisata air sumber bantal. Selain itu, perlu ditambah gazebo atau tempat duduk yang rimbun agar para wisatawan yang berkunjung tidak kepanasan saat beristirahat pada siang hari dan tetap merasa nyaman selama berada di obyek wisata air sumber bantal tersebut.

b. Upaya untuk meningkatkan jumlah wisatawan

Upaya untuk meningkatkan jumlah wisatawan yang berkunjung ke obyek wisata air sumber bantal salah satunya adalah dengan menggunakan sistem promosi. Promosi yang dilakukan warga sekitar yang bekerjasama dengan pemerintahan desa Jambangan. Selain itu, rekan-rekan KKN juga berusaha mempromosikan obyek wisata air sumber bantal melalui media sosial seperti instagram, facebook, whatapps, dan aplikasi sosial media lainnya. Promosi dengan menggunakan media sosial dianggap lebih efektif dan efisien.

c. Kendala-kendala dalam mengembangkan obyek wisata air sumber bantal

Di dalam kesuksesan yang diraih banyak terjadi kendala-kendala yang dihadapi dari tahun ke tahun baik kendala internal maupun eksternal. Karena hasil yang telah dicapai tersebut obyek pariwisata harus bisa mempertahankan untuk dijadikan sebagai dasar untuk mengambil tindakan dalam memajukan dan mengembangkan obyek pariwista yang telah ada menjadi lebih baik di masa depan. Kendala yang dihadapi oleh pengelola dan pemerintah desa Jambangan salah satunya adalah tentang hak milik. Karena lahan atau tanah di sekitar obyek.

Wisata air sumber bantal masih berstatus hak milik warga sekitar. Dan warga sekitar tidak mau menjual tanah - tanah mereka kepada pengelola dikarenakan menurut warga sekitar tanah mereka yang berada di sekitar daerah wisata air sumber bantal merupakan asset. Akan tetapi pengelola dan pemerintah desa Jambangan tidak khawatir karena menurut mereka kendala tersebut dapat diatasi dan diminimalisir, yaitu dengan cara mengikutsertakan warga sekitar dalam membantu mengelola tempat wisata air sumber bantal.

\section{KESIMPULAN}

Desa Jambangan, Kecamatan Dampit, Kabupaten Malang meruapakan salah satu wilayah yang berpotensi di bidang pariwisata. Wilayah ini berpotensi sebagai area wisata karena banyak tempat-tempat wisata yang menyuguhkan keindahan alam yang tercipta dengan alami. Dan yang dibahas disini adalah wisata air sumber bantal. Obyek wisata air sumber bantal menjadi potensi utama di desa Jambangan dengan suasana yang masih asri dan sejuk. Keindahan tersebut dapat dilihat dari pemandangan yang tercipta secara alami, tekstur tanah, dan kemurnian air. Jadi obyek wisata air sumber bantal ini sangat cocok sekali untuk para wisatawan baik anak muda atau yang sudah berkeluarga, baik wisatawan domestik maupun non-domestik.

Konsep yang digunakan dalam pengembangan obyek wisata air sumber bantal adalah bertumpu pada alam. Artinya dalam konsep pengembangan obyek wisata air 
sumber bantal tidak menghilangkan unsure nilai alamiah. Maka dari itu, pengelola dan pemerintahan desa Jambangan berusaha mengoptimalkan potensi yang ada di obyek wisata air sumber bantal.

Upaya untuk meningkatkan jumlah wisatawan yang berkunjung ke obyek wisata air sumber bantal salah satunya adalah dengan menggunakan sistem promosi. Promosi yang dilakukan warga sekitar yang bekerjasama dengan pemerintahan desa Jambangan. Selain itu, juga juga perlu berusaha mempromosikan obyek wisata air sumber bantal melalui media sosial seperti instagram, facebook, whatapps, dan aplikasi sosial media lainnya.

Kendala yang dihadapi oleh pengelola dan pemerintah desa Jambangan salah satunya adalah tentang hak milik. Karena lahan atau tanah di sekitar obyek wisata air sumber bantal masih berstatus hak milik warga sekitar. Dan warga sekitar tidak mau menjual tanah-tanah mereka kepada pengelola dikarenakan menurut warga sekitar tanah mereka yang berada di sekitar daerah wisata air sumber bantal merupakan asset.

\section{DAFTAR RUJUKAN}

Al-Qur'anul Karim.

Rio Nur Desnanto. 2013. "Analisis Potensi Wisata Alam untuk Pengembangan Wisata di Kabupaten Karanganyar". http://eprints.ums.ac.id/25205/13/08 Artikel Ilmiah.pdf, diakses pada tanggal 6 Maret 2019 pukul 10.05.

J.S. Badudu. 1995. Kamus Umum Bahasa Indonesia. Jakarta: Pustaka Sinar Harapan.

Kotler, Philip dan Amstrong. 2001. Prinsip-prinsip Pemasaran (terjemahan Philip, Kotler, Amstrong). Jakarta: Erlangga.

Lamb, Hair, McDaniel. 2001. Pemasaran (terjemahan David Oktarevia). Edisi Pertama. Jakarta: Salemba Empat.

Sugiyono. 2011. Metode Penelitian Kuantitatif, Kualitatif dan R\&D. Bandung: Alfabeta.

Swastha, Basu dan Irawan. 1990. Manajemen Pemasaran Modern. Yogyakarta: Liberty. 